\title{
PRECISE-DAPT score for bleeding risk prediction in patients on dual or single antiplatelet regimens: insights from the GLOBAL LEADERS and GLASSY
}

Felice Gragnano, MD,${ }^{1}$ Dik Heg, PhD ${ }^{2}$ Anna Franzone, MD, PhD ${ }^{3}$ Eugène P. McFadden, MD,${ }^{4}$ Sergio Leonardi, MD, MHS, ${ }^{5}$ Raffaele Piccolo, MD, PhD ${ }^{3}$ Pascal Vranckx, MD, PhD, ${ }^{6}$ Mattia Branca, ${ }^{2}$ Patrick W. Serruys, MD, PhD, ${ }^{7}$ Edouard Benit, MD,${ }^{8}$ Christoph Liebetrau, MD, ${ }^{9}$ Luc Janssens, MD, ${ }^{10}$ Maurizio Ferrario, MD, ${ }^{5}$ Aleksander Zurakowski, MD, ${ }^{11}$ Roberto Diletti, MD, $\mathrm{PhD},{ }^{12}$ Marcello Dominici, MD ${ }^{13}$ Kurt Huber, MD ${ }^{14}$ Ton Slagboom, MD ${ }^{15}$ Paweł Buszman, MD ${ }^{16}$ Leonardo Bolognese, MD,${ }^{17}$ Carlo Tumscitz, MD ${ }^{18}$ Krzysztof Bryniarski, MD, PhD,${ }^{19}$ Adel Aminian, MD,${ }^{20}$ Mathias Vrolix, MD ${ }^{21}$ Ivo Petrov, MD, ${ }^{22}$ Scot Garg, MD, PhD ${ }^{23}$ Christoph Naber, $\mathrm{MD},{ }^{24}$ Janusz Prokopczuk, MD,${ }^{25}$ Christian Hamm, MD ${ }^{26}$ Philippe Gabriel Steg, ${ }^{27} \mathrm{MD}$, Peter Jüni, $\mathrm{MD},{ }^{28}$ Stephan Windecker, MD, ${ }^{1}$ Marco Valgimigli, MD, PhD,${ }^{29}$ for the GLASSY Investigators

${ }^{1}$ Department of Cardiology, Inselspital, University of Bern;

${ }^{2}$ Institute of Social and Preventive Medicine and Clinical Trials Unit, University of Bern, Bern, Switzerland;

${ }^{3}$ Department of Advanced Biomedical Sciences, Federico II University of Naples, Naples, Italy; ${ }^{4}$ Cardialysis Core Laboratories and Clinical Trial Management, Rotterdam, the Netherlands and Department of Cardiology, Cork University Hospital, Cork, Ireland;

${ }^{5}$ University of Pavia and Fondazione IRCCS Policlinico S.Matteo, Pavia, Italy;

${ }^{6}$ Department of Cardiology and Critical Care Medicine, Hartcentrum Hasselt, Jessa Ziekenhuis, Belgium;

${ }^{7}$ Department of Cardiology, Imperial College of London, London, United Kingdom;

${ }^{8}$ Jessa Hospital, Department of Cardiology, Hasselt, Belgium;

${ }^{9}$ Department of Cardiology, Kerckhoff Heart and Thorax Center, Bad Nauheim, Germany and German Center for Cardiovascular Research (DZHK), partner site RheinMain, Frankfurt am Main, Germany;

${ }^{10}$ Imelda Hospital, Bonheiden, Belgium;

${ }^{11}$ Center of Cardiovascular Research and Development, American Heart of Poland, Katowice, Poland;

${ }^{12}$ Thoraxcenter, Erasmus Medical Center, Rotterdam, the Netherlands;

${ }^{13}$ S. Maria University-Hospital,Terni, Italy;

${ }^{14}$ 3rd Medical Department, Cardiology, Wilhelminenhospital, and Sigmund Freud University

Medical School, Vienna, Austria;

${ }^{15}$ OLVG Amsterdam, Amsterdam, the Netherlands;

${ }^{16}$ Center for Cardiovascular Research and Development American Heart of Poland, and Department of Epidemiology, Medical University of Silesia, Katowice, Poland;

${ }^{17}$ Azienda Toscana Usl Sudest, Arezzo, Italy;

${ }^{18}$ Cardiology Unit Sant'Anna Hospital, Ferrara, Italy;

${ }^{19}$ Jagiellonian University Medical College, The John Paul II Hospital, Krakow, Poland;

${ }^{20}$ Department of cardiology, Centre Hospitalier Universitaire de Charleroi, Charleroi, Belgium;

${ }^{21}$ Ziekenhuis Oost Limburg, Genk, Belgium;

${ }^{22}$ Acibadem City Clinic Cardiovascular Center, Sofia, Bulgaria;

${ }^{23}$ East Lancashire Hospitals NHS Trust, Blackburn, UK;

${ }^{24}$ Klinikum Wilhelmshaven, Wilhelmshaven, Germany;

${ }^{25}$ PAKS Kozle, Poland;

${ }^{26}$ Department of Cardiology, Kerckhoff Heart and Thorax Center, Bad Nauheim, Germany and German Center for Cardiovascular Research (DZHK); Partner site RheinMain, Frankfurt am Main, Germany;

${ }^{27}$ Hôpital Bichat, AP-HP, Université Paris-Diderot, Paris, France; 
${ }^{28}$ Applied Health Research Centre, Li Ka Shing Knowledge Institute of St Michael's Hospital, Department of Medicine, University of Toronto, Ontario, Canada;

${ }^{29}$ Cardiocentro Ticino, Lugano, Switzerland.

Word count (including text, references, table, and figure legends): 5,674

Short title: PRECISE-DAPT score in Dual or Single Antiplatelet Therapy

Address for correspondence:

Prof. Marco Valgimigli

Cardiocentro Ticino

Via Tesserete 48

CH- 6900 Lugano, Switzerland

marco.valgimigli@cardiocentro.org

Phone/Fax: +41918053347 


\section{ASTRACT}

Aims. The 5-item PRECISE-DAPT, integrating age, haemoglobin, white-blood-cell count, creatinine clearance, and prior bleeding, predicts bleeding risk in patients on dual antiplatelet therapy (DAPT) after stent implantation. We sought to assess whether the bleeding risk prediction offered by the PRECISE-DAPT remains valid among patients receiving ticagrelor monotherapy from 1 month onwards after coronary stenting instead of standard DAPT and having or not having centrally-adjudicated bleeding endpoints.

Methods and results. The PRECISE-DAPT was calculated in 14,928 and 7,134 patients from GLOBAL LEADERS and GLASSY trials, respectively. The ability of the score to predict BARC 3 or 5 bleeding was assessed and compared among patients on ticagrelor monotherapy (experimental strategy) or standard DAPT (reference strategy) from 1 month after drug-eluting stent implantation. Bleeding endpoints were investigator-reported or centrally-adjudicated in GLOBAL LEADERS and GLASSY, respectively.

At 2 years, the c-indexes for the score among patients treated with the experimental or reference strategy were 0.67 (95\% confidence interval [CI]:0.63-0.71) vs. 0.63 (95\% CI:0.59-0.67) in GLOBAL LEADERS (p=0.27), and 0.67 (95\% CI:0.61-0.73) vs. 0.66 (95\% CI:0.61-0.72) in GLASSY ( $\mathrm{p}=0.88$ ). Decision curve analysis showed net benefit using the PRECISE-DAPT to guide bleeding risk assessment under both treatment strategies. Results were consistent between investigator-reported and adjudicated endpoints and using the simplified 4-item PRECISE-DAPT. Conclusions. The PRECISE-DAPT offers a prediction model that proved similarly effective to predict clinically-relevant bleeding among patients on ticagrelor monotherapy from 1 month after coronary stenting compared with standard DAPT and appears to be unaffected by the presence or absence of adjudicated bleeding endpoints.

Keywords: Dual antiplatelet therapy; Ticagrelor; Aspirin; Bleeding; Percutaneous coronary intervention. 


\section{Introduction}

Dual antiplatelet therapy (DAPT) reduces the risk of stent-related and spontaneous ischaemic events in patients undergoing percutaneous coronary intervention (PCI). ${ }^{1-4}$ This benefit comes with an increased risk of bleeding, which can offset the ischemic benefit and adversely impact prognosis. ${ }^{3,4}$ Therefore, the assessment of bleeding risk after PCI is crucial to guide clinicians' decisions with respect to antiplatelet therapies. ${ }^{1,5}$ The PRECISE-DAPT is a 5-item score that has been developed to predict bleeding risk during $\mathrm{DAPT}^{6}$ and was endorsed by a Class IIB recommendation to identify high bleeding risk patients (i.e., score $\geq 25$ ), in whom the benefits of shorter DAPT (i.e., 3-6 months) can outweigh the risks of extended treatment duration. ${ }^{1,7}$ Since its generation, the performance of the score has been tested in contemporary PCI cohorts treated with standard DAPT consisting of aspirin plus a P2Y12 inhibitor (i.e., 6 to 12 months) followed by aspirin monotherapy. ${ }^{8-10}$ Recently, several trials have challenged current DAPT paradigm and provided evidence that early discontinuation of aspirin followed by the continuation of potent P2Y12 inhibitors is able to reduce overall bleeding risks without an apparent trade-off in efficacy. ${ }^{11-14}$ Whether PRECISE-DAPT score retains consistent bleeding risk prediction capability in patients receiving potent P2Y12 inhibitor monotherapy is unclear. Moreover, no study so far has assessed whether the PRECISE-DAPT performance might be affected by the presence or absence of centrally-adjudicated bleeding endpoints, which carries relevant implications for practice. The GLOBAL LEADERS trial ${ }^{11}$ and its Adjudication Sub-Study (GLASSY) ${ }^{15}$ randomized patients to receive 1-month DAPT followed by 23-month ticagrelor monotherapy or 12-month DAPT followed by aspirin alone after new-generation drug-eluting stenting.

We sought to assess the performance of PRECISE-DAPT score to predict bleeding risk in patients receiving either ticagrelor $90 \mathrm{mg}$ twice daily monotherapy from 1 month after PCI or standard DAPT in the setting of GLOBAL LEADERS, based on investigator-reported endpoints, and GLASSY, based on centrally-adjudicated endpoints. 


\section{Methods}

\section{Study design and participants}

GLOBAL LEADERS (NCT01813435) is a multicenter randomized trial investigating two antiplatelet strategies in all-comer patients receiving drug-eluting stent for acute coronary syndromes (ACS) or stable coronary artery disease (CAD). ${ }^{11}$ After coronary angiography, 15,991 patients were randomized (1:1) using a web-based-system stratified by center and clinical presentation. The experimental strategy consisted of 1-month DAPT (aspirin 75-100 mg plus ticagrelor $90 \mathrm{mg}$ bid) followed by 23-month ticagrelor $90 \mathrm{mg}$ bid monotherapy. The reference strategy consisted of standard 12-month DAPT (aspirin 75-100 mg plus clopidogrel $75 \mathrm{mg}$ if stable CAD or ticagrelor $90 \mathrm{mg}$ bid if ACS) followed by aspirin alone for 12 months.

GLASSY (NCT03231059) is a sub-study of the GLOBAL LEADERS including adjudicated events from all 7,585 patients enrolled at the 20 highest recruiting sites, whereby investigator-reported events and triggered potential unreported events were centrally adjudicated by an independent Clinical Events Committee (CEC) blinded to treatment groups. ${ }^{15}$ All participants provided written informed consent. The protocols were approved by ethic committees of participating institutions.

\section{PRECISE-DAPT score calculation}

The PRECISE-DAPT is a 5-item bleeding risk score, which has been generated for the prediction of Thrombosis in Myocardial Infarction (TIMI) out-of-hospital bleeding in patients on DAPT using age, creatinine clearance, white-blood-cell count, haemoglobin, and history of bleeding at baseline. ${ }^{6}$ The PRECISE-DAPT has the potential to inform clinicians' decision with respect to the optimal DAPT duration post PCI, selecting high bleeding risk patients (score $\geq 25$ ) for a shorter treatment (i.e., 3-6 months) and non-high-risk patients for prolonged treatment (i.e., $\geq 12$ months). A simplified 4-item version of the score, lacking white-blood-cells count, has also been developed and validated. ${ }^{16}$ In the present analysis, PRECISE-DAPT was calculated and assigned to each 
participant as in the development cohort. The simplified 4-item version of the score was also computed. ${ }^{6}$ All data for score calculations were prospectively collected.

\section{Study endpoints}

The primary endpoint was bleeding type 3 or 5 defined according to the Bleeding Academic Research Consortium (BARC) scale, ${ }^{17}$ which was investigator-reported in GLOBAL LEADERS and CEC-adjudicated in GLASSY. The primary endpoint was analyzed in the overall populations and separately in the experimental and control groups, and across 2 years or with landmark at 1 year.

\section{Statistical analysis}

The PRECISE-DAPT score was calculated using data collected at index PCI. Patients were stratified into 4 groups according to study treatment and PRECISE-DAPT ( $\geq 25$ vs. $<25$ ). Continuous variables are expressed as mean (standard deviation) or median (interquartile range), and categorical variables as numbers and percentages. Differences were calculated using t-test and Wilcoxon-test for continuous data and $\chi^{2}$ or Fisher's tests for categorical data. Kaplan-Meier method was used to estimate cumulative event rates and log-rank test to examine differences across score strata. The association between the primary endpoint and risk categories was calculated as hazard ratios (HR), considering very-low risk patients as reference. Discrimination was assessed using Harrell's c-statistic, and compared through treatment strategies using a nonparametric test. Calibration was assessed by Grønnesby-Borgan $\chi^{2}$ test and plotted as observed versus predicted outcomes using Arjas plots. Continuous relation between the risk (as hazard ratio) and incidence of BARC 3 or 5 bleeding at follow-up and PRECISE-DAPT was assessed using restricted cubic splines. Net clinical benefit was determined by means of decision curve analyses. ${ }^{18}$ All analyses were performed at 2 years and with landmark at 1 year. A two-sided $p<0.05$ was considered 
statistically significant. Analyses were performed using STATA 16.1 (Stata Corp., College Station, Texas).

\section{Results}

\section{Study patients}

Of the 15,991 and 7,585 patients enrolled in GLOBAL LEADERS and GLASSY, the PRECISEDAPT was available in 14,928 (93.3\%) and 7,134 (94.0\%), respectively. The mean score was $16.5 \pm 8.8$ in the parental trial and $16.5 \pm 8.7$ in the adjudication sub-study, while the median score was 15.0 (interquartile range:10.0; 21.0) in both studies (Tables 1 and 2). A total of 2,483 (16.6\%) patients in GLOBAL LEADERS and 1,180 (16.5\%) in GLASSY had a PRECISE-DAPT score $\geq 25$. Score distribution was similar in the experimental and control groups (Figure 1).

In both studies, baseline characteristics were well balanced between the experimental and control group within PRECISE-DAPT strata (Tables 1 and 2 and supplementary material). Patients with high versus non-high PRECISE-DAPT differed for the 5 score covariates and were more frequently female, had lower body-mass index and higher rates of cardiovascular risk factors, prior myocardial infarction, coronary revascularization, and stroke; they also received less frequent radial access, single lesion intervention, or direct stenting.

\section{Bleeding risk stratification by PRECISE-DAPT score}

The risk of bleeding as estimated by Kaplan-Meier event curves differed significantly according to PRECISE-DAPT score with similar stratification effect for the experimental and reference strategy (Figure 2). At 2 years, GLOBAL LEADERS patients with PRECISE-DAPT $\geq 25$ had significantly increased risk of BARC 3 or 5 bleeding in both the experimental group (HR:4.37; 95\% CI:2.647.23; $\mathrm{p}<0.001)$ and control group (HR:3.81; 95\% CI:2.30-6.30; $\mathrm{p}<0.001)$ compared with the reference (score $\leq 10$ ). In GLASSY, patients with high PRECISE-DAPT showed an HR of 4.71 in 
the experimental group (95\% CI:2.44-9.07; p<0.001) and of 3.39 in the control group (95\%

CI:1.78-6.57; p<0.001). Results were consistent in the overall study populations (Figure S1). The PRECISE-DAPT showed a continuous association with the risk (in terms of hazard ratio) as well as the incidence of BARC 3 or 5 bleeding at 1 year and 2 years, which was consistent between the experimental and control groups (Figure 3, and Figures S2 and S3).

\section{PRECISE-DAPT performance for bleeding prediction}

PRECISE-DAPT was effective to predict BARC 3 or 5 bleeding in patients receiving either the experimental or reference strategy (Tables 3 and 4, Figures S4 and S5).

In GLOBAL LEADERS, the score showed moderate discrimination with c-index of 0.67 (95\% CI:0.63-0.71) in the experimental group vs. 0.63 (95\% CI:0.59-0.67) in the control group at 2 years $(\mathrm{p}=0.27)$. In GLASSY, the c-index was 0.67 (95\% CI:0.61-0.73) in the experimental group and 0.66 (95\% CI:0.61-0.72) in the control group ( $\mathrm{p}=0.88)$. The score was moderately calibrated in both treatment strategies, although the predicted and observed probability approximated more closely in GLOBAL LEADERS than GLASSY.

Results were consistent at landmark analysis. In GLOBAL LEADERS, c-index estimates during the first and second year of follow-up were 0.68 and 0.64 in the experimental group, and 0.62 and 0.66 in the control group, respectively. Similarly, in GLASSY, c-index values before and after the 1-year landmark were 0.69 and 0.61 in the experimental arm, and 0.64 and 0.75 in the control arm (Tables 3 and 4, Figure S5).

Discriminative ability of the 4-item PRECISE-DAPT was similar to the score including whiteblood-cell count and consistent with respect to randomized treatment strategies, although this score iteration appeared less well calibrated (Tables 3 and 4, Figure S6).

\section{Net clinical benefit}


Figure 4 compares the decision curves to classify individuals using PRECISE-DAPT and its 4-item version assuming that all patients will bleed (i.e., all are at high risk of bleeding) or that no patient will bleed (i.e., all are at low risk of bleeding). For BARC 3 or 5 bleeding, decision curves showed that both scores were superior to the scenario of "not using scores" for risk thresholds from $1 \%$ to 8\% in all study groups (Figure 2, Figure S4). For instance, in the experimental group of GLOBAL LEADERS, applying a risk threshold of $3 \%$ for BARC 3 or 5 events, the use of PRECISE-DAPT would result in a net benefit gain of $+0.27 \%(+0.32 \%$ for the 4 -item score $)$ and of $+1.12 \%(1.17 \%$ for the 4-item score) compared with the scenario of "assuming all as high-risk" (Table S3). In other words, the net benefit of using the PRECISE-DAPT score leads to 37.3 (39 for the 4-item score) and 9 (10.6 for the 4-item score) more true-positive cases per 100 patients without additional falsepositives (i.e., "net" true-positives) compared with "assuming all as high-risk" and "assuming all as low-risk", respectively. Additional case examples are reported in Tables S4-S6.

\section{Discussion}

In the current analysis, which included more than 14,000 participants of the GLOBAL LEADERS trial and its GLASSY sub-study, we evaluated the performance of PRECISE-DAPT score in patients having or not adjudicated bleeding endpoints and treated with ticagrelor plus aspirin for 1 month followed by 23-month ticagrelor monotherapy or standard 12-month DAPT followed by aspirin monotherapy after PCI. The main findings are the following:

- The PRECISE-DAPT score was able to stratify bleeding risk to a similar extent in patients with or without DAPT, consisting of a 12-month combination of aspirin and ticagrelor or aspirin and clopidogrel followed by 12-month aspirin monotherapy or 23-month ticagrelor monotherapy from 1-month after coronary stenting.

- The score provided modest but consistent discrimination and good calibration for the prediction of BARC-defined bleeding in both study arms, with a net benefit compared with the scenario of not using risk scores. 
- The score performance remained consistent for bleeding prediction within the first year, where mainly ticagrelor monotherapy was compared with a DAPT regimen, as well as during the second year, where ticagrelor monotherapy was compared with aspirin monotherapy.

- The score performance remained comparable when investigator-reported bleeding, within GLOBAL LEADERS, or centrally-adjudicated bleeding endpoints, within GLASSY, were separately appraised.

- The 4-item PRECISE-DAPT score appeared very similar to the 5-item iteration, offering a credible option for bleeding risk assessment if white-blood-cell count is not available. Current guidelines recommend with a class IIB - pending prospective validation - the use of bleeding prediction models to individualize DAPT duration in patients undergoing PCI. ${ }^{1,6}$ The PRECISE-DAPT score was developed in a large PCI-treated population receiving standard antiplatelet treatment, typically consisting of DAPT for 6 to 12 months followed by aspirin alone after P2Y12 inhibitors discontinuation. ${ }^{3,6}$ Multiple studies have assessed the score performance showing a consistent ability to predict bleeding among patients receiving standard DAPT. ${ }^{8-10}$ Yet, recent studies have challenged current DAPT paradigm by investigating the potential of early aspirin discontinuation after PCI. The GLOBAL LEADERS ${ }^{11}$ and its Adjudication Sub-study GLASSY $^{15}$ pioneered this approach and provided reassuring data on the safety and efficacy of ticagrelor monotherapy, but failed to show its superiority over standard DAPT. In the STOPDAPT$2^{12}$ and SMART-CHOICE, ${ }^{13}$ P2Y12 monotherapy - principally clopidogrel - after 1 or 3 months of DAPT was associated with a lower incidence of bleeding than 12-month DAPT, without an apparent difference in ischemic endpoints. The TWILIGHT ${ }^{14}$ and $\mathrm{TICO}^{19}$ trials provided additional support by demonstrating lower bleeding risks with ticagrelor monotherapy (after 3-month DAPT) over conventional treatment while preserving ischemic efficacy.

Whether the PRECISE-DAPT score retains its potential to reasonably forecast bleeding in patients undergoing treatment with a single antiplatelet agent, including a potent P2Y12 inhibitor or aspirin, 
remains unclear. In addition, PRECISE-DAPT was generated and externally validated in the context of centrally-adjudicated bleeding endpoints, and it remained unclear if its performance might be affected by investigator-reported endpoints.

We showed that PRECISE-DAPT, as well as its 4-item simplified version, retains a similar capacity to stratify bleeding risk in PCI patients on ticagrelor monotherapy after 1-month DAPT as among those on standard DAPT. Regardless of the assigned treatment, the higher the score, the higher the risk of clinically-relevant bleeding, which increased by a factor of more than two in patients with 18-24 points and more than 4 -fold in those with $\geq 25$ points. In GLASSY, a PRECISE-DAPT score of 25 conferred a 1-year risk of adjudicated BARC 3 or 5 bleeding that approximated $4 \%$ at the upper limit of the $95 \% \mathrm{CI}$ - a threshold that has been recently proposed to select high bleeding risk patients by the Academic Research Consortium (ARC) for High Bleeding Risk. ${ }^{5}$ The lower rate of BARC 3 or 5 events in GLOBAL LEADERS compared with GLASSY might be explained by the underreporting of clinical events due to the use of investigator-reported versus centrally-adjudicated endpoints, respectively. In addition, the use of PRECISE-DAPT was consistently better than "not using risk scores" at decision curve analysis, irrespective of the implemented antiplatelet treatment. Indeed, under both treatment strategies, we observed a net benefit in terms of fewer false-positive cases across a wide range of bleeding risk thresholds, in the absence of any potential drawbacks. Of note, despite the pragmatic study design, the proportion of patients with score $\geq 25$ in GLOBAL LEADERS and GLASSY was approximately $16 \%$ and relatively low compared with previous studies. $^{6,9}$

During ticagrelor monotherapy, similarly to standard DAPT, PRECISE-DAPT was reasonably accurate to distinguish patients who would have bled from those who would have not (discrimination) and predicted the level of risk subsequently observed in reality (calibration). We noticed a slightly better score calibration in the parental trial, while the c-index estimates were slightly higher but less precise (in terms of 95\% CI) in GLASSY. The evaluation of scores performance requires appropriate sample size of preferably $\geq 100$ events, whereas a lower number of 
events can negatively affect calibration and (to a lesser extent) c-index estimates. ${ }^{20}$ GLASSY included about half of patients and events included in the parent trial, and this may reasonably account for the less precise calibration and c-index estimates observed in this cohort, with a less apparent effect on the latter.

No other risk score has been so far tested for bleeding risk prediction with ticagrelor monotherapy. Several risk scores have been designed to predict in-hospital or 30-day bleeding (i.e., CRUSADE, ACUITY). At variance from these models, PRECISE-DAPT predicts long-term bleeding risk and therefore appears more suited for patients on ticagrelor monotherapy after a short course of DAPT. The comparative performance of PRECISE-DAPT versus other bleeding risk scores remains unclear.

We also observed that score performance remained consistent among patients receiving aspirin monotherapy (i.e., reference group during the second year). Though interesting, these data should be interpreted cautiously considering the low number of events in this sub-group.

Applying the score to GLOBAL LEADERS and GLASSY gave us the opportunity to test the score in the context of investigator-reported or adjudicated bleeding events. Our data showed the ability of PRECISE-DAPT to offer consistent bleeding prediction inside and outside the context of CECadjudication, which carries relevant implications for practice.

In the present analysis, PRECISE-DAPT performance was reasonable in both GLOBAL LEADERS and GLASSY (c-index of 0.65 and 0.67 , respectively), but somewhat lower than that reported in the derivation and PLATO cohorts (c-index of 0.73 and 0.70 , respectively). ${ }^{6}$ The relative performance of the score in different studies can be explained, at least in part, by differences in bleeding definitions and patients' characteristics. At variance with our analysis, which included all post-PCI bleeding graded by BARC scale, the score has been developed to predict out-of-hospital bleeding according to TIMI scale. ${ }^{6}$ Noteworthy, when the score had been tested in its derivation cohort to predict all post-PCI bleeding (rather than out-of-hospital events), its discriminative ability for TIMI major or minor occurrences was slightly lower (c-index of 0.68 ) and closer to our estimates. 
Moreover, when BARC 3 or 5 bleeding has been used as endpoint, the score has shown a c-index of 0.69 and 0.65 for post-PCI and post-discharge bleeding, respectively, in contemporary PCI registries, ${ }^{6,10}$ in line with our findings. A recent study of 904 PCI patients showed a c-index of 0.81 for $\mathrm{BARC} \geq 3 \mathrm{a} .{ }^{8}$ However, the retrospective design, small sample size, the exclusive inclusion of Asian patients, and much higher than expected BARC $\geq 3$ a bleeding (17\% at 1 year) potentially limit data generalizability. ${ }^{8}$ Higher score performance for predicting BARC 3 or 5 bleeding (c-index of 0.73 ) has also been reported in $1,926 \mathrm{ACS}$ patients. ${ }^{9}$ Yet, differences in bleeding characterization (out-of-hospital events assessed through medical records), population's characteristics, and study design can possibly account for these discrepancies ${ }^{9}$.

Our study has several limitations. First, this analysis was prespecified, yet the results should be considered hypothesis-generating. Second, the PRECISE-DAPT was not available in approximately $6 \%$ of patients that were excluded. Third, differences in bleeding definition used as compared with the derivation cohort may have affected the score performance. Finally, approximately $20 \%$ of GLOBAL LEADERS and GLASSY patients were non-adherent to study treatment. Prior on- versus off-treatment analyses suggested higher score performance for the former compared with the latter.

\section{Conclusions}

The PRECISE-DAPT consistently predicts bleeding risk in patients on ticagrelor monotherapy after 1-month DAPT or on aspirin monotherapy after 12-month DAPT as compared with patients on standard DAPT after drug-eluting stent implantation. Our analysis also suggests that the score performance is unaffected by the presence or absence of adjudicated bleeding endpoints, which carries relevant implications for practice. 


\section{Funding}

The GLOBAL LEADERS study was supported by the European Clinical Research Institute, which received funding from AstraZeneca, Biosensors International and The Medicines Company. The study funders had no role in trial design, data collection, analysis and interpretation of the data. The authors received no funding for the present sub-analysis.

\section{Acknowledgments}

None.

\section{Conflicts of interest}

Dr. McFadden reports personal fees and non-financial support from University of Bern, during the conduct of the study; personal fees from Daiichi Sankyo Europe, non-financial support from Astra Zeneca Ireland, outside the submitted work.

Dr. Leonardi reports grants and personal fees from AstraZeneca and Bayer, outside the submitted work.

Dr. Vranckx reports personal fees from Astra Zeneca and The Medicines Company, during the conduct of the study; personal fees from Terumo, CLS Bhering, Daiichi Sankyo, Bayer Health Care, outside the submitted work.

Dr. Serruys has received personal fees from Abbott, Biosensors, Cardialysis, Medtronic, Sinomedical Sciences, Philips/Volcano, Xeltis, and HeartFlow; and has received consultancy fees from Abbott Laboratories, Biosensors, Cardialysis, Medtronic, Sino Medical Sciences Technology, Philips/Volcano, Xeltis, and HeartFlow.

Dr. Diletti reports grants from AstraZeneca, outside the submitted work.

Dr. Steg reports grants and personal fees from Bayer/Janssen, Merck, Sanofi, Amarin, Servier, personal fees from Amgen, Bristol Myers Squibb, Boehringer-Ingelheim, Pfizer, Novartis, Regeneron, Lilly, AstraZeneca, outside the submitted work. 
Dr. Naber reports personal fees from Abbott, Medtronic, Bionsesors, Biotronik, outside the submitted work.

Dr. Hamm reports personal fees from AstraZeneca, during the conduct of the study.

Dr. Heg and Dr. Branca are affiliated with CTU Bern, University of Bern, which has a staff policy of not accepting honoraria or consultancy fees. However, CTU Bern is involved in design, conduct, or analysis of clinical studies funded by not-for-profit and for-profit organizations. In particular, pharmaceutical and medical device companies provide direct funding to some of these studies. For an up-to-date list of CTU Bern's conflicts of interest see

http://www.ctu.unibe.ch/research/declaration_of_interest/index_eng.html.

Dr. Windecker reports research and educational grants to the institution from Abbott, Amgen, BMS, Bayer, Boston Scientific, Biotronik, Cardinal Health, CSL Behring, Daiichi Sankyo, Edwards Lifesciences, Johnson\&Johnson, Medtronic, Querbet, Polares, Sanofi, Terumo, Sinomed, outside the submitted work.

Dr. Jüni serves as unpaid member of the steering group of trials funded by Astra Zeneca, Biotronik, Biosensors, St. Jude Medical and The Medicines Company.

Dr. Valgimigli reports grants and personal fees from Abbott, Astrazeneca and Terumo, personal fees from Chiesi, Bayer, Daiichi Sankyo, Amgen, Alvimedica, Biosensors, and Idorsia, grants from Medicure, outside the submitted work.

All other Authors reported no relationships relevant to the contents of this paper to disclose.

\section{Data Availability Statement}

The data underlying this article will be shared on reasonable request to the corresponding author. 


\section{References}

1. Valgimigli M, Bueno H, Byrne RA, Collet J-P, Costa F, Jeppsson A, Jüni P, Kastrati A, Kolh P, Mauri L, Montalescot G, Neumann F-J, Petricevic M, Roffi M, Steg PG, Windecker S, Zamorano JL, Levine GN, ESC Scientific Document Group, ESC Committee for Practice Guidelines (CPG), ESC National Cardiac Societies. 2017 ESC focused update on dual antiplatelet therapy in coronary artery disease developed in collaboration with EACTS: The Task Force for dual antiplatelet therapy in coronary artery disease of the European Society of Cardiology (ESC) and of the European. Eur Heart J 2018;39:213-260.

2. Wallentin L, Becker RC, Budaj A, Cannon CP, Emanuelsson H, Held C, Horrow J, Husted S, James S, Katus H, Mahaffey KW, Scirica BM, Skene A, Steg PG, Storey RF, Harrington RA. Ticagrelor versus Clopidogrel in Patients with Acute Coronary Syndromes. N Engl J Med 2009;361:1045-1057.

3. Valgimigli M, Campo G, Monti M, Vranckx P, Percoco G, Tumscitz C, Castriota F, Colombo F, Tebaldi M, Fucà G, Kubbajeh M, Cangiano E, Minarelli M, Scalone A, Cavazza C, Frangione A, Borghesi M, Marchesini J, Parrinello G, Ferrari R. Short- Versus LongTerm Duration of Dual-Antiplatelet Therapy After Coronary Stenting. Circulation 2012;125:2015-2026.

4. Mauri L, Kereiakes DJ, Yeh RW, Driscoll-Shempp P, Cutlip DE, Steg PG, Normand S-LT, Braunwald E, Wiviott SD, Cohen DJ, Holmes DR, Krucoff MW, Hermiller J, Dauerman HL, Simon DI, Kandzari DE, Garratt KN, Lee DP, Pow TK, Lee P Ver, Rinaldi MJ, Massaro JM. Twelve or 30 Months of Dual Antiplatelet Therapy after Drug-Eluting Stents. N Engl J Med 2014;371:2155-2166.

5. Ueki Y, Bär S, Losdat S, Otsuka T, Zanchin C, Zanchin T, Gragnano F, Gargiulo G, Siontis GCM, Praz F, Lanz J, Hunziker L, Stortecky S, Pilgrim T, Heg D, Valgimigli M, Windecker S, Räber L. Validation of Bleeding Risk Criteria (ARC-HBR) in Patients Undergoing Percutaneous Coronary Intervention and Comparison with Contemporary Bleeding Risk 
Scores. EuroIntervention 2020.

6. Costa F, Klaveren D van, James S, Heg D, Räber L, Feres F, Pilgrim T, Hong M-KK, Kim H-SS, Colombo A, Steg PG, Zanchin T, Palmerini T, Wallentin L, Bhatt DL, Stone GW, Windecker S, Steyerberg EW, Valgimigli M, PRECISE-DAPT Study Investigators. Derivation and validation of the predicting bleeding complications in patients undergoing stent implantation and subsequent dual antiplatelet therapy (PRECISE-DAPT) score: a pooled analysis of individual-patient datasets from clinical trials. Lancet 2017;389:10251034.

7. Neumann FJ, Sousa-Uva M, Ahlsson A, Alfonso F, Banning AP, Benedetto U, Byrne RA, Collet J-P, Falk V, Head SJ, Jüni P, Kastrati A, Koller A, Kristensen SD, Niebauer J, Richter DJ, Seferović PM, Sibbing D, Stefanini GG, Windecker S, Yadav R, Zembala MO, Wijns W, Glineur D, Aboyans V, Achenbach S, Agewall S, Andreotti F, Barbato E, Baumbach A, et al. 2018 ESC/EACTS Guidelines on myocardial revascularization. Eur Heart J 2019;40:87-165.

8. Choi SY, Kim MH, Cho Y-R, Sung Park J, Min Lee K, Park T-H, Yun S-C. Performance of PRECISE-DAPT Score for Predicting Bleeding Complication During Dual Antiplatelet Therapy. Circ Cardiovasc Interv 2018;11:e06837.

9. Abu-Assi E, Raposeiras-Roubin S, Cobas-Paz R, Caneiro-Queija B, Martínez-Reglero C, Rodríguez-Rodríguez JM, Baz A, Íñiguez-Romo A. Assessing the performance of the PRECISE-DAPT and PARIS risk scores for predicting one-year out-of-hospital bleeding in acute coronary syndrome patients. EuroIntervention 2018;13:1914-1922.

10. Bianco M, D’ascenzo F, Raposeiras Roubin S, Kinnaird T, Peyracchia M, Ariza-Solé A, Cerrato E, Manzano-Fernández S, Gravinese C, Templin C, Destefanis P, Velicki L, Luciano A, Xanthopoulou I, Rinaldi M, Rognoni A, Varbella F, Boccuzzi G, Omedè P, Montabone A, Bernardi A, Taha S, Rossini R, Durante A, Gili S, Magnani G, Autelli M, Grosso A, Blanco PF, Giustetto C, et al. Comparative external validation of the PRECISE-DAPT and PARIS risk scores in 4424 acute coronary syndrome patients treated with prasugrel or ticagrelor. Int 
J Cardiol 2020;301:200-206.

11. Vranckx P, Valgimigli M, Jüni P, Hamm C, Steg PG, Heg D, Es GA van, McFadden EP, Onuma Y, Meijeren C van, Chichareon P, Benit E, Möllmann H, Janssens L, Ferrario M, Moschovitis A, Zurakowski A, Dominici M, Geuns RJ van, Huber K, Slagboom T, Serruys PW, Windecker S, Abdellaoui M, Adlam D, Akin I, Albarran Gonzalez-Trevilla A, Almeida M, Alves Lemos Neto P, Aminian A, et al. Ticagrelor plus aspirin for 1 month, followed by ticagrelor monotherapy for 23 months vs aspirin plus clopidogrel or ticagrelor for 12 months, followed by aspirin monotherapy for 12 months after implantation of a drug-eluting stent: a multicentre, open-la. Lancet 2018;392:940-949.

12. Watanabe H, Domei T, Morimoto T, Natsuaki M, Shiomi H, Toyota T, Ohya M, Suwa S, Takagi K, Nanasato M, Hata Y, Yagi M, Suematsu N, Yokomatsu T, Takamisawa I, Doi M, Noda T, Okayama H, Seino Y, Tada T, Sakamoto H, Hibi K, Abe M, Kawai K, Nakao K, Ando K, Tanabe K, Ikari Y, Hanaoka KI, Morino Y, et al. Effect of 1-Month Dual Antiplatelet Therapy Followed by Clopidogrel vs 12-Month Dual Antiplatelet Therapy on Cardiovascular and Bleeding Events in Patients Receiving PCI. JAMA 2019;321:2414.

13. Hahn J-Y, Song Y Bin, Oh J-H, Chun WJ, Park YH, Jang WJ, Im E-S, Jeong J-O, Cho BR, Oh SK, Yun KH, Cho D-K, Lee J-Y, Koh Y-Y, Bae J-W, Choi JW, Lee WS, Yoon HJ, Lee SU, Cho JH, Choi WG, Rha S-W, Lee JM, Park TK, Yang JH, Choi J-H, Choi S-H, Lee SH, Gwon H-C. Effect of P2Y12 Inhibitor Monotherapy vs Dual Antiplatelet Therapy on Cardiovascular Events in Patients Undergoing Percutaneous Coronary Intervention. JAMA 2019;321:2428.

14. Mehran R, Baber U, Sharma SK, Cohen DJ, Angiolillo DJ, Briguori C, Cha JY, Collier T, Dangas G, Dudek D, Džavík V, Escaned J, Gil R, Gurbel P, Hamm CW, Henry T, Huber K, Kastrati A, Kaul U, Kornowski R, Krucoff M, Kunadian V, Marx SO, Mehta SR, Moliterno D, Ohman EM, Oldroyd K, Sardella G, Sartori S, Shlofmitz R, et al. Ticagrelor with or without Aspirin in High-Risk Patients after PCI. N Engl J Med 2019;381:2032-2042. 
15. Franzone A, McFadden E, Leonardi S, Piccolo R, Vranckx P, Serruys PW, Benit E, Liebetrau C, Janssens L, Ferrario M, Zurakowski A, Diletti R, Dominici M, Huber K, Slagboom T, Buszman P, Bolognese L, Tumscitz C, Bryniarski K, Aminian A, Vrolix M, Petrov I, Garg S, Naber C, Prokopczuk J, Hamm C, Steg PG, Heg D, Jüni P, Windecker S, et al. Ticagrelor Alone Versus Dual Antiplatelet Therapy From 1 Month After Drug-Eluting Coronary Stenting. J Am Coll Cardiol 2019;74:2223-2234.

16. Costa F, van Klaveren D, Colombo A, Feres F, Räber L, Pilgrim T, Hong M-K, Kim HS, Windecker S, Steyerberg EW, Valgimigli M. A 4-item PRECISE-DAPT score for dual antiplatelet therapy duration decision-making. Am Heart J 2020;223:44-47.

17. Mehran R, Rao S V., Bhatt DL, Gibson CM, Caixeta A, Eikelboom J, Kaul S, Wiviott SD, Menon V, Nikolsky E, Serebruany V, Valgimigli M, Vranckx P, Taggart D, Sabik JF, Cutlip DE, Krucoff MW, Ohman EM, Steg PG, White H. Standardized Bleeding Definitions for Cardiovascular Clinical Trials. Circulation 2011;123:2736-2747.

18. Vickers AJ, Elkin EB. Decision Curve Analysis: A Novel Method for Evaluating Prediction Models. Med Decis Mak 2006;26:565-574.

19. Yangsoo Jang MP. Ticagrelor With or Without Aspirin in Acute Coronary Syndrome After PCI (TICO). American College of Cardiology Annual Scientific Session 2020.

20. Collins GS, Ogundimu EO, Altman DG. Sample size considerations for the external validation of a multivariable prognostic model: a resampling study. Stat Med 2016;35:214226. 
Table 1. Baseline characteristics of the GLOBAL LEADERS population stratified by PRECISE-

DAPT.

\begin{tabular}{|c|c|c|c|c|c|c|c|}
\hline & \multicolumn{3}{|c|}{ PRECISE-DAPT $\geq 25$} & \multicolumn{3}{|c|}{ PRECISE-DAPT $<25$} & \multirow[b]{2}{*}{$\begin{array}{c}\text { p-value } \\
\geq 25 \text { vs. } \\
<25\end{array}$} \\
\hline & $\begin{array}{c}\text { Experimental } \\
\text { group } \\
(\mathbf{n}=\mathbf{1 , 2 4 8})\end{array}$ & $\begin{array}{c}\text { Control } \\
\text { group } \\
(n=1,235)\end{array}$ & $\begin{array}{c}\text { p- } \\
\text { value }\end{array}$ & $\begin{array}{c}\text { Experimental } \\
\text { group } \\
(\mathbf{n}=\mathbf{6 , 2 1 0})\end{array}$ & $\begin{array}{c}\text { Control } \\
\text { group } \\
(n=6,235)\end{array}$ & $\begin{array}{c}\text { p- } \\
\text { value }\end{array}$ & \\
\hline Age (years) & $74.9 \pm 8.0$ & $75.0 \pm 7.9$ & 0.58 & $62.5 \pm 9.5$ & $62.5 \pm 9.5$ & 0.93 & $<0.001$ \\
\hline Females & $499(40.0 \%)$ & $\begin{array}{c}470 \\
(38.1 \%)\end{array}$ & 0.34 & $1,261(20.3 \%)$ & $\begin{array}{c}1,241 \\
(19.9 \%)\end{array}$ & 0.57 & $<0.001$ \\
\hline $\begin{array}{l}\text { Body mass index } \\
\left(\mathrm{kg} / \mathrm{m}^{2}\right)\end{array}$ & $28.0 \pm 4.5$ & $27.9 \pm 4.7$ & 0.59 & $28.2 \pm 4.6$ & $28.3 \pm 4.6$ & 0.69 & 0.001 \\
\hline Diabetes mellitus & $465(37.3 \%)$ & $\begin{array}{c}432 \\
(35.0 \%)\end{array}$ & 0.22 & $1,463(23.6 \%)$ & $\begin{array}{c}1,446 \\
(23.2 \%)\end{array}$ & 0.62 & $<0.001$ \\
\hline $\begin{array}{l}\text { Insulin-dependent } \\
\text { diabetes mellitus }\end{array}$ & $174(14.0 \%)$ & $\begin{array}{c}176 \\
(14.3 \%)\end{array}$ & 0.86 & $389(6.3 \%)$ & $\begin{array}{c}402 \\
(6.5 \%)\end{array}$ & 0.68 & $<0.001$ \\
\hline Hypertension & $1,092(87.6 \%)$ & $\begin{array}{c}1,019 \\
(82.7 \%)\end{array}$ & 0.001 & $4,475(72.3 \%)$ & $\begin{array}{c}4,486 \\
(72.2 \%)\end{array}$ & 0.87 & $<0.001$ \\
\hline Hypercholesterolemia & $847(70.3 \%)$ & $\begin{array}{c}854 \\
(70.8 \%)\end{array}$ & 0.82 & $4,167(69.5 \%)$ & $\begin{array}{c}4,253 \\
(70.5 \%)\end{array}$ & 0.23 & 0.55 \\
\hline Current smoker & $160(12.8 \%)$ & $\begin{array}{c}154 \\
(12.5 \%)\end{array}$ & 0.80 & $1,776(28.6 \%)$ & $\begin{array}{c}1,830 \\
(29.4 \%)\end{array}$ & 0.36 & $<0.001$ \\
\hline $\begin{array}{l}\text { Previous myocardial } \\
\text { infarction }\end{array}$ & $309(24.8 \%)$ & $\begin{array}{c}332 \\
(27.0 \%)\end{array}$ & 0.23 & $1,408(22.7 \%)$ & $\begin{array}{c}1,450 \\
(23.3 \%)\end{array}$ & 0.45 & 0.002 \\
\hline Previous PCI & $433(34.8 \%)$ & $\begin{array}{c}461 \\
(37.4 \%)\end{array}$ & 0.18 & $2,013(32.4 \%)$ & $\begin{array}{c}2,008 \\
(32.2 \%)\end{array}$ & 0.81 & $<0.001$ \\
\hline $\begin{array}{l}\text { Previous coronary } \\
\text { artery by-pass graft }\end{array}$ & $107(8.6 \%)$ & $\begin{array}{c}127 \\
(10.3 \%)\end{array}$ & 0.15 & $307(4.9 \%)$ & $\begin{array}{c}342 \\
(5.5 \%)\end{array}$ & 0.18 & $<0.001$ \\
\hline Previous stroke & $57(4.6 \%)$ & $60(4.9 \%)$ & 0.77 & $142(2.3 \%)$ & $\begin{array}{c}138 \\
(2.2 \%)\end{array}$ & 0.80 & $<0.001$ \\
\hline $\begin{array}{l}\text { Peripheral vascular } \\
\text { disease }\end{array}$ & $125(10.1 \%)$ & $\begin{array}{c}130 \\
(10.6 \%)\end{array}$ & 0.74 & $324(5.3 \%)$ & $\begin{array}{c}365 \\
(5.9 \%)\end{array}$ & 0.12 & $<0.001$ \\
\hline $\begin{array}{l}\text { Previous major } \\
\text { bleeding }\end{array}$ & $43(3.5 \%)$ & $47(3.8 \%)$ & 0.66 & $0(0.0 \%)$ & $0(0.0 \%)$ & - & $<0.001$ \\
\hline $\begin{array}{l}\text { Impaired renal } \\
\text { function }\end{array}$ & $721(57.8 \%)$ & $\begin{array}{c}694 \\
(56.2 \%)\end{array}$ & 0.44 & $329(5.3 \%)$ & $\begin{array}{c}322 \\
(5.2 \%)\end{array}$ & 0.74 & $<0.001$ \\
\hline $\begin{array}{l}\text { Chronic obstructive } \\
\text { pulmonary disease }\end{array}$ & $104(8.4 \%)$ & $103(8.4 \%)$ & 1.00 & $278(4.5 \%)$ & $\begin{array}{c}293 \\
(4.7 \%)\end{array}$ & 0.54 & $<0.001$ \\
\hline \multicolumn{8}{|l|}{ Clinical presentation } \\
\hline $\begin{array}{l}\text { Stable coronary artery } \\
\text { disease }\end{array}$ & $619(49.6 \%)$ & $\begin{array}{c}637 \\
(51.6 \%) \\
\end{array}$ & 0.33 & $3,255(52.4 \%)$ & $\begin{array}{c}3,255 \\
(52.2 \%)\end{array}$ & 0.81 & 0.11 \\
\hline $\begin{array}{l}\text { Acute coronary } \\
\text { syndrome }\end{array}$ & $629(50.4 \%)$ & $\begin{array}{c}598 \\
(48.4 \%)\end{array}$ & 0.33 & $2,955(47.6 \%)$ & $\begin{array}{c}2,980 \\
(47.8 \%)\end{array}$ & 0.81 & 0.11 \\
\hline Unstable angina & $161(12.9 \%)$ & $\begin{array}{c}148 \\
(12.0 \%)\end{array}$ & 0.50 & $813(13.1 \%)$ & $\begin{array}{c}842 \\
(13.5 \%)\end{array}$ & 0.50 & 0.25 \\
\hline Non-STEMI & $272(21.8 \%)$ & $\begin{array}{c}301 \\
(24.4 \%)\end{array}$ & 0.12 & $1,329(21.4 \%)$ & $\begin{array}{c}1,323 \\
(21.2 \%)\end{array}$ & 0.81 & 0.05 \\
\hline STEMI & $196(15.7 \%)$ & $\begin{array}{c}149 \\
(12.1 \%)\end{array}$ & 0.009 & $813(13.1 \%)$ & $\begin{array}{c}815 \\
(13.1 \%) \\
\end{array}$ & 0.97 & 0.28 \\
\hline \multicolumn{8}{|l|}{ PRECISE-DAPT } \\
\hline Mean score & $31.4 \pm 6.6$ & $31.0 \pm 6.3$ & 0.11 & $13.6 \pm 5.8$ & $13.6 \pm 5.8$ & 0.96 & \\
\hline Median score & $\begin{array}{c}29.0 \\
(27.0 ; 34.0)\end{array}$ & $\begin{array}{c}29.0 \\
(27.0 ; 33.0)\end{array}$ & 0.28 & $\begin{array}{c}14.0 \\
(9.0 ; 18.0) \\
\end{array}$ & $\begin{array}{c}14.0 \\
(9.0 ; 18.0) \\
\end{array}$ & 0.95 & \\
\hline
\end{tabular}

Sample sizes (n); counts (\%); means ( \pm standard deviations) or medians (25\%-75\% interquartile range).

PCI, percutaneous coronary intervention; STEMI, ST-segment elevation myocardial infarction. 
Table 2. Baseline characteristics of the GLASSY population stratified by PRECISE-DAPT.

\begin{tabular}{|c|c|c|c|c|c|c|c|}
\hline & \multicolumn{3}{|c|}{ PRECISE-DAPT score $\geq 25$} & \multicolumn{3}{|c|}{ PRECISE-DAPT score $<25$} & \multirow[b]{2}{*}{$\begin{array}{c}\text { p-value } \\
\geq 25 \text { vs. } \\
<25\end{array}$} \\
\hline & $\begin{array}{c}\text { Experimental } \\
\text { group } \\
(\mathbf{n}=607)\end{array}$ & $\begin{array}{c}\text { Control } \\
\text { group } \\
(n=573)\end{array}$ & $\begin{array}{c}\text { p- } \\
\text { value }\end{array}$ & $\begin{array}{c}\text { Experimental } \\
\text { group } \\
(\mathbf{n}=\mathbf{2 , 9 5 6 )}\end{array}$ & $\begin{array}{c}\text { Control } \\
\text { group } \\
(\mathrm{n}=2,998)\end{array}$ & $\begin{array}{c}\text { p- } \\
\text { value }\end{array}$ & \\
\hline Age (years) & $75.5 \pm 7.7$ & $75.9 \pm 7.6$ & 0.48 & $62.8 \pm 9.4$ & $62.7 \pm 9.5$ & 0.62 & $<0.001$ \\
\hline Females & $256(42.2 \%)$ & $\begin{array}{c}225 \\
(39.3 \%)\end{array}$ & 0.31 & $606(20.5 \%)$ & $\begin{array}{c}603 \\
(20.1 \%)\end{array}$ & 0.72 & $<0.001$ \\
\hline Body mass index $\left(\mathrm{kg} / \mathrm{m}^{2}\right)$ & $27.8 \pm 4.3$ & $27.5 \pm 4.4$ & 0.32 & $28.0 \pm 4.6$ & $28.0 \pm 4.5$ & 0.75 & 0.02 \\
\hline Diabetes mellitus & $213(35.1 \%)$ & $\begin{array}{c}195 \\
(34.0 \%)\end{array}$ & 0.71 & $656(22.2 \%)$ & $\begin{array}{c}663 \\
(22.1 \%)\end{array}$ & 0.95 & $<0.001$ \\
\hline $\begin{array}{l}\text { Insulin-dependent } \\
\text { diabetes mellitus }\end{array}$ & $80(13.2 \%)$ & $75(13.1 \%)$ & 1.00 & $166(5.6 \%)$ & $175(5.8 \%)$ & 0.73 & $<0.001$ \\
\hline Hypertension & $525(86.5 \%)$ & $\begin{array}{c}473 \\
(82.5 \%)\end{array}$ & 0.06 & $2,117(71.6 \%)$ & $\begin{array}{c}2,146 \\
(71.6 \%)\end{array}$ & 1.00 & $<0.001$ \\
\hline Hypercholesterolemia & $397(65.4 \%)$ & $\begin{array}{c}379 \\
(66.1 \%)\end{array}$ & 0.89 & $1,897(64.2 \%)$ & $\begin{array}{c}2,002 \\
(66.8 \%)\end{array}$ & 0.02 & 0.72 \\
\hline Current smoker & $96(15.8 \%)$ & $83(14.5 \%)$ & 0.57 & $932(31.5 \%)$ & $\begin{array}{c}962 \\
(32.1 \%)\end{array}$ & 0.65 & $<0.001$ \\
\hline $\begin{array}{l}\text { Previous myocardial } \\
\text { infarction }\end{array}$ & $149(24.5 \%)$ & $\begin{array}{c}165 \\
(28.8 \%)\end{array}$ & 0.09 & $666(22.5 \%)$ & $\begin{array}{c}683 \\
(22.8 \%)\end{array}$ & 0.85 & 0.004 \\
\hline Previous PCI & $204(33.6 \%)$ & $\begin{array}{c}234 \\
(40.8 \%)\end{array}$ & 0.01 & $950(32.1 \%)$ & $\begin{array}{c}984 \\
(32.8 \%)\end{array}$ & 0.58 & 0.002 \\
\hline $\begin{array}{l}\text { Previous coronary } \\
\text { artery by-pass graft }\end{array}$ & $39(6.4 \%)$ & $55(9.6 \%)$ & 0.05 & $154(5.2 \%)$ & $170(5.7 \%)$ & 0.45 & 0.001 \\
\hline Previous stroke & $33(5.4 \%)$ & $25(4.4 \%)$ & 0.42 & $62(2.1 \%)$ & $66(2.2 \%)$ & 0.79 & $<0.001$ \\
\hline $\begin{array}{l}\text { Peripheral vascular } \\
\text { disease }\end{array}$ & $79(13.0 \%)$ & $74(12.9 \%)$ & 1.00 & $165(5.6 \%)$ & $207(6.9 \%)$ & 0.03 & $<0.001$ \\
\hline Previous major bleeding & $25(4.1 \%)$ & $18(3.1 \%)$ & 0.43 & $0(0.0 \%)$ & $0(0.0 \%)$ & - & $<0.001$ \\
\hline Impaired renal function & $349(57.5 \%)$ & $\begin{array}{c}315 \\
(55.0 \%)\end{array}$ & 0.41 & $142(4.8 \%)$ & $152(5.1 \%)$ & 0.67 & $<0.001$ \\
\hline $\begin{array}{l}\text { Chronic obstructive } \\
\text { pulmonary disease }\end{array}$ & $53(8.7 \%)$ & $56(9.8 \%)$ & 0.61 & $136(4.6 \%)$ & $139(4.6 \%)$ & 0.95 & $<0.001$ \\
\hline \multicolumn{8}{|l|}{ Clinical presentation } \\
\hline $\begin{array}{l}\text { Stable coronary artery } \\
\text { disease }\end{array}$ & $260(42.8 \%)$ & $\begin{array}{c}268 \\
(46.8 \%)\end{array}$ & 0.17 & $1,449(49.0 \%)$ & $\begin{array}{c}1,488 \\
(49.6 \%)\end{array}$ & 0.64 & 0.004 \\
\hline $\begin{array}{l}\text { Acute coronary } \\
\text { syndrome }\end{array}$ & $347(57.2 \%)$ & $\begin{array}{c}305 \\
(53.2 \%)\end{array}$ & 0.17 & $1,507(51.0 \%)$ & $\begin{array}{c}1,510 \\
(50.4 \%)\end{array}$ & 0.64 & 0.004 \\
\hline Unstable angina & $83(13.7 \%)$ & $67(11.7 \%)$ & 0.33 & $392(13.3 \%)$ & $\begin{array}{c}418 \\
(13.9 \%)\end{array}$ & 0.45 & 0.42 \\
\hline Non-STEMI & $138(22.7 \%)$ & $\begin{array}{c}148 \\
(25.8 \%)\end{array}$ & 0.22 & $588(19.9 \%)$ & $\begin{array}{c}559 \\
(18.6 \%)\end{array}$ & 0.22 & $<0.001$ \\
\hline STEMI & $126(20.8 \%)$ & $90(15.7 \%)$ & 0.02 & $527(17.8 \%)$ & $\begin{array}{c}533 \\
(17.8 \%)\end{array}$ & 0.97 & 0.67 \\
\hline \multicolumn{8}{|l|}{ PRECISE-DAPT } \\
\hline Mean score & $31.3 \pm 6.7$ & $30.6 \pm 5.9$ & 0.68 & $13.6 \pm 5.7$ & $13.6 \pm 5.8$ & 0.65 & \\
\hline Median score & $\begin{array}{c}29.0 \\
(26.0 ; 34.0)\end{array}$ & $\begin{array}{c}29.0 \\
(26.0 ; 33.0)\end{array}$ & 0.27 & $\begin{array}{c}14.0 \\
(9.0 ; 18.0)\end{array}$ & $\begin{array}{c}14.0 \\
(9.0 ; 18.0)\end{array}$ & 0.69 & \\
\hline
\end{tabular}

Sample sizes (n), counts (\%), means ( \pm standard deviations) or medians (25\%-75\% interquartile range).

PCI, percutaneous coronary intervention; STEMI, ST-segment elevation myocardial infarction. 
Table 3. Harrell's c-indexes and goodness-of-fit for BARC 3 or 5 bleeding in GLOBAL LEADERS.

\begin{tabular}{|c|c|c|c|c|c|c|c|c|c|c|c|c|c|}
\hline & \multicolumn{4}{|c|}{ Overall } & \multicolumn{4}{|c|}{ Experimental group } & \multicolumn{4}{|c|}{ Control group } & \multirow[b]{2}{*}{$\begin{array}{c}\text { p-value } \\
\text { c-index } \\
\text { experim } \\
\text { ental vs } \\
\text { control }\end{array}$} \\
\hline & $\begin{array}{c}\text { BARC } 3 \\
\text { or } 5 / n \text {. } \\
\text { patients }\end{array}$ & $\begin{array}{c}\text { c-index } \\
(95 \% \mathrm{CI})\end{array}$ & $\begin{array}{c}\text { Grønnesby } \\
\text {-Borgan } \\
\text { LR } \chi^{2}\end{array}$ & $\begin{array}{c}\text { p- } \\
\text { value }\end{array}$ & $\begin{array}{c}\text { BARC } 3 \\
\text { or } 5 / n \text {. } \\
\text { patients }\end{array}$ & $\begin{array}{c}\text { c-index } \\
(95 \% \text { CI })\end{array}$ & $\begin{array}{c}\text { Grønnesby } \\
\text {-Borgan } \\
\text { LR } \chi^{2}\end{array}$ & $\begin{array}{c}\text { p- } \\
\text { value }\end{array}$ & $\begin{array}{c}\text { BARC } 3 \\
\text { or } 5 / n . \\
\text { patients }\end{array}$ & $\begin{array}{c}\text { c-index } \\
(95 \% \mathrm{CI})\end{array}$ & $\begin{array}{c}\text { Grønnesby } \\
\text {-Borgan } \\
\text { LR } \chi^{2}\end{array}$ & $\begin{array}{c}\text { p- } \\
\text { value }\end{array}$ & \\
\hline \multicolumn{14}{|l|}{ At 1 Year } \\
\hline PRECISE-DAPT & $244 /$ & $\begin{array}{c}0.65 \\
(0.61-0.68)\end{array}$ & 2.3 & 0.79 & $\begin{array}{c}113 / \\
7,458\end{array}$ & $\begin{array}{c}0.68 \\
(0.63-0.73)\end{array}$ & 1.5 & 0.91 & $\begin{array}{c}131 / \\
7,470\end{array}$ & $\begin{array}{c}0.62 \\
(0.58-0.67)\end{array}$ & 2.6 & 0.75 & 0.27 \\
\hline \multicolumn{14}{|l|}{ At 2 Years } \\
\hline PRECISE-DAPT & \multirow{2}{*}{$\begin{array}{c}322 / \\
14,928\end{array}$} & $\begin{array}{c}0.65 \\
(0.62-0.68)\end{array}$ & 2.7 & 0.75 & \multirow{2}{*}{$\begin{array}{c}159 / \\
7,458\end{array}$} & $\begin{array}{c}0.67 \\
(0.63-0.71)\end{array}$ & 2.3 & 0.81 & \multirow{2}{*}{$\begin{array}{l}163 / \\
7,470\end{array}$} & $\begin{array}{c}0.63 \\
(0.59-0.67)\end{array}$ & 2.8 & 0.73 & 0.27 \\
\hline $\begin{array}{c}\text { 4-item } \\
\text { PRECISE-DAPT }\end{array}$ & & $\begin{array}{c}0.65 \\
(0.61-0.67) \\
\end{array}$ & 7.8 & 0.16 & & $\begin{array}{c}0.68 \\
(0.64-0.72) \\
\end{array}$ & 11 & 0.05 & & $\begin{array}{c}0.61 \\
(0.57-0.65) \\
\end{array}$ & 5.2 & 0.39 & 0.14 \\
\hline \multicolumn{14}{|l|}{ Landmark 1-2 years } \\
\hline $\begin{array}{c}\text { 4-item } \\
\text { PRECISE-DAPT }\end{array}$ & 14,302 & $\begin{array}{c}0.67 \\
(0.62-0.73) \\
\end{array}$ & 4.5 & 0.48 & 7,145 & $\begin{array}{c}0.69 \\
(0.61-0.76) \\
\end{array}$ & 3.2 & 0.67 & $\begin{array}{c}32 / \\
7,157\end{array}$ & $\begin{array}{c}0.66 \\
(0.57-0.75) \\
\end{array}$ & 13.6 & 0.01 & 0.74 \\
\hline
\end{tabular}

BARC, Bleeding Academic Research Consortium; CI, confidence interval. 
Table 4. Harrell's c-indexes and goodness-of-fit for BARC 3 or 5 bleeding in GLASSY.

\begin{tabular}{|c|c|c|c|c|c|c|c|c|c|c|c|c|c|}
\hline & \multicolumn{4}{|c|}{ Overall } & \multicolumn{4}{|c|}{ Experimental group } & \multicolumn{4}{|c|}{ Control group } & \multirow[b]{2}{*}{$\begin{array}{c}\text { p-value } \\
\text { c-index } \\
\text { experim } \\
\text { ental vs. } \\
\text { control }\end{array}$} \\
\hline & $\begin{array}{c}\text { BARC } 3 \\
\text { or } 5 / n . \\
\text { patients }\end{array}$ & $\begin{array}{c}\text { c-index } \\
(95 \% \mathrm{CI})\end{array}$ & $\begin{array}{c}\text { Grønnesby } \\
\text {-Borgan } \\
\text { LR } \chi^{2}\end{array}$ & $\begin{array}{c}\text { p- } \\
\text { value }\end{array}$ & $\begin{array}{c}\text { BARC } 3 \\
\text { or } 5 / n \text {. } \\
\text { patients }\end{array}$ & $\begin{array}{l}\text { c-index } \\
(95 \% \text { CI })\end{array}$ & 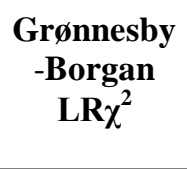 & $\begin{array}{c}\text { p- } \\
\text { value }\end{array}$ & $\begin{array}{c}\text { BARC } 3 \\
\text { or } 5 / n . \\
\text { patients }\end{array}$ & $\begin{array}{c}\text { c-index } \\
(95 \% \text { CI })\end{array}$ & $\begin{array}{c}\text { Grønnesby } \\
\text {-Borgan } \\
\text { LR } \chi^{2}\end{array}$ & $\begin{array}{c}\text { p- } \\
\text { value }\end{array}$ & \\
\hline \multicolumn{14}{|l|}{ At 1 Year } \\
\hline PRECISE-DAPT & $140 /$ & $\begin{array}{c}0.66 \\
(0.62-0.71)\end{array}$ & 4.3 & 0.51 & \multirow{2}{*}{$66 / 3,563$} & $\begin{array}{c}0.69 \\
(0.62-0.75)\end{array}$ & 5.1 & 0.40 & \multirow{2}{*}{$74 / 3,571$} & $\begin{array}{c}0.64 \\
(0.58-0.71)\end{array}$ & 6.5 & 0.26 & 0.50 \\
\hline $\begin{array}{c}\text { 4-item } \\
\text { PRECISE-DAPT }\end{array}$ & 7,134 & $\begin{array}{c}0.66 \\
(0.61-0.70)\end{array}$ & 6.6 & 0.25 & & $\begin{array}{c}0.70 \\
(0.63-0.76)\end{array}$ & 5.1 & 0.40 & & $\begin{array}{c}0.63 \\
(0.57-0.69)\end{array}$ & 4.7 & 0.45 & 0.30 \\
\hline \multicolumn{14}{|l|}{ At 2 Years } \\
\hline PRECISE-DAPT & $181 /$ & $\begin{array}{c}0.67 \\
(0.63-0.71)\end{array}$ & 4.5 & 0.48 & \multirow{2}{*}{$90 / 3,563$} & $\begin{array}{c}0.67 \\
(0.61-0.73)\end{array}$ & 5.9 & 0.31 & \multirow{2}{*}{$91 / 3,571$} & $\begin{array}{c}0.66 \\
(0.61-0.72)\end{array}$ & 7.3 & 0.19 & 0.88 \\
\hline $\begin{array}{c}\text { 4-item } \\
\text { PRECISE-DAPT }\end{array}$ & 7,134 & $\begin{array}{c}0.67 \\
(0.63-0.71)\end{array}$ & 9.5 & 0.09 & & $\begin{array}{c}0.69 \\
(0.63-0.74)\end{array}$ & 7.4 & 0.19 & & $\begin{array}{c}0.65 \\
(0.60-0.71)\end{array}$ & 5.6 & 0.34 & 0.51 \\
\hline \multicolumn{14}{|l|}{ Landmark 1-2 years } \\
\hline PRECISE-DAPT & \multirow{2}{*}{$41 / 6,827$} & $\begin{array}{c}0.67 \\
(0.58-0.76)\end{array}$ & 5.6 & 0.34 & \multirow{2}{*}{$24 / 3,412$} & $\begin{array}{c}0.61 \\
(0.49-0.73)\end{array}$ & 3.2 & 0.66 & \multirow{2}{*}{$17 / 3,415$} & $\begin{array}{c}0.75 \\
(0.64-0.87)\end{array}$ & 2.9 & 0.71 & 0.42 \\
\hline $\begin{array}{c}\text { 4-item } \\
\text { PRECISE-DAPT }\end{array}$ & & $\begin{array}{c}0.70 \\
(0.62-0.78)\end{array}$ & 7.3 & 0.19 & & $\begin{array}{c}0.66 \\
(0.55-0.77)\end{array}$ & 5.3 & 0.37 & & $\begin{array}{c}0.74 \\
(0.62-0.86)\end{array}$ & 9.3 & 0.09 & 0.30 \\
\hline
\end{tabular}

BARC, Bleeding Academic Research Consortium; CI, confidence interval. 


\section{Figure Legends}

Figure 1. PRECISE-DAPT score distribution in GLOBAL LEADERS and GLASSY according to the treatment strategy. Experimental and control groups in GLOBAL LEADERS (A,B) and GLASSY (C,D).

Figure 2. BARC 3 or 5 bleeding at 2 years in GLOBAL LEADERS and GLASSY stratified by PRECISE-DAPT score. Kaplan-Meier event curves for BARC 3 or 5 bleeding at 2 years. Experimental and control groups in GLOBAL LEADERS $(\mathrm{A}, \mathrm{C})$ and GLASSY (B,D). BARC, Bleeding Academic Research Consortium Criteria; HR, Hazard ratio.

Figure 3. Spline functions of BARC 3 or 5 bleeding risk at 2 years according to PRECISEDAPT. Experimental and control groups in GLOBAL LEADERS (A), and GLASSY (B). BARC, Bleeding Academic Research Consortium Criteria; CI, confidence interval; HR, hazard ratio.

Figure 4. Decision curves showing net benefit of using the PRECISE-DAPT or the 4-item PRECISE-DAPT for predicting BARC 3 or 5 bleeding at 2 years. Experimental and control groups in GLOBAL LEADERS (A,B) and GLASSY (C,D). Black horizontal line: treat all assuming at low risk of bleeding. Green line: treat all assuming at high-risk of bleeding. Red curve: PRECISE-DAPT. Yellow curve: 4-item PRECISE-DAPT. Decision curves are drawn by plotting net benefit (y-axis) at different risk thresholds ( $\mathrm{x}$-axis) to visually estimate and compare the benefit offered by different strategies. BARC, Bleeding Academic Research Consortium Criteria. 


\section{GLOBAL LEADERS}

A

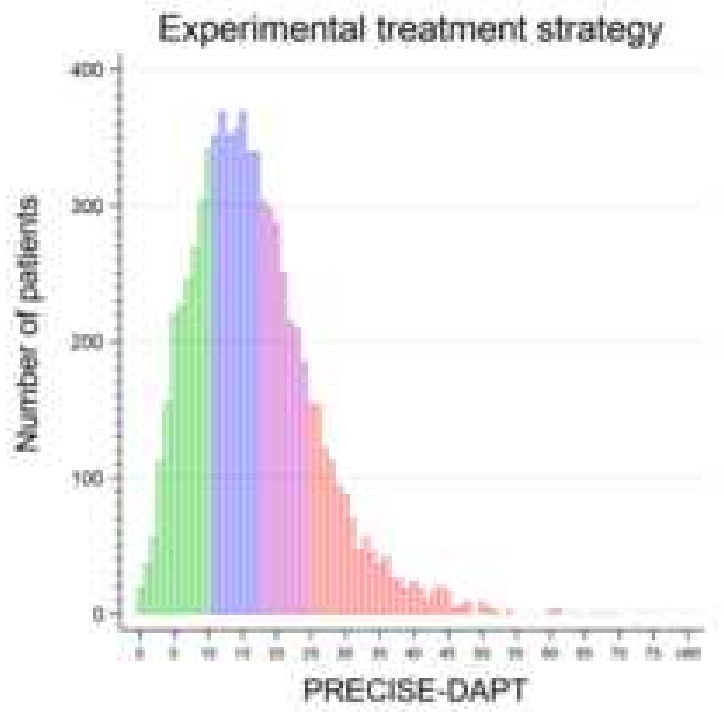

B

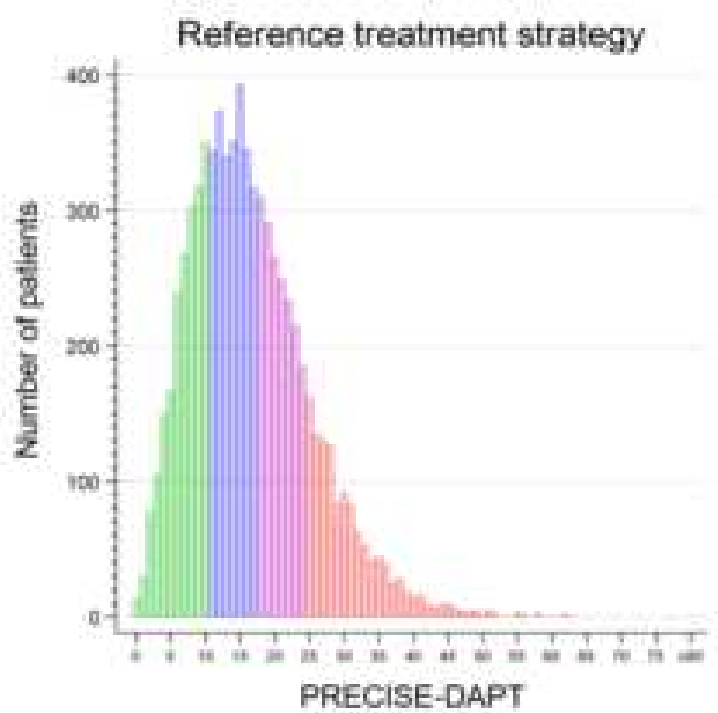

\section{GLASSY}

D

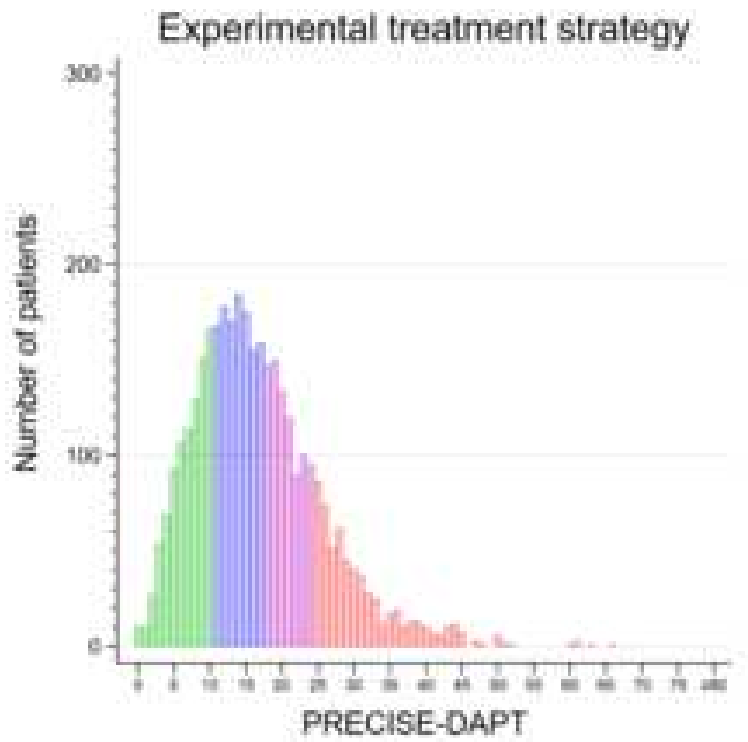

11] Verylow rink (PRECISE-0APT 0-10)

a Low risk (PReCISE-ONPT 11-17)

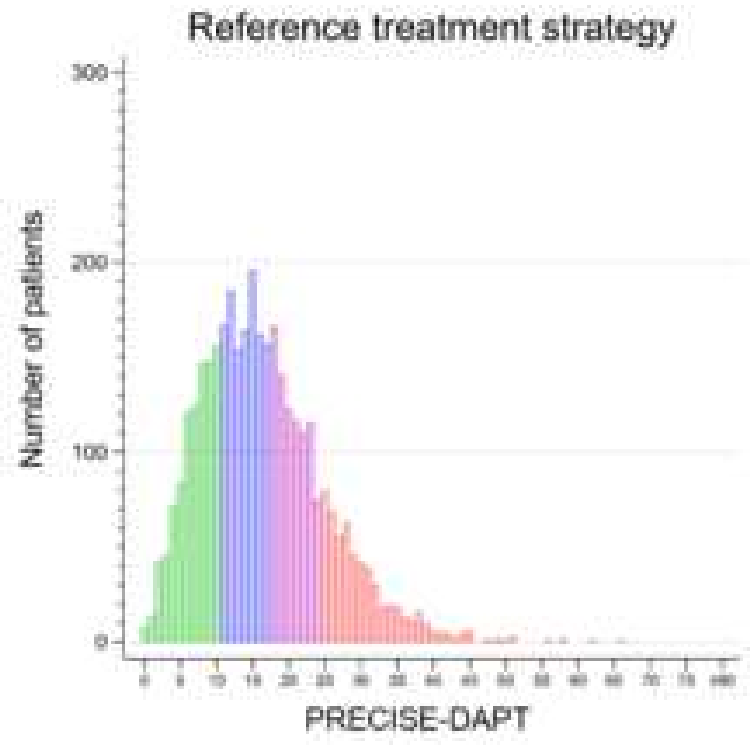

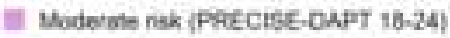

all High nak (PRECISE-DAPT 225) 


\section{GLOBAL LEADERS}

A

\section{Experimental Group}

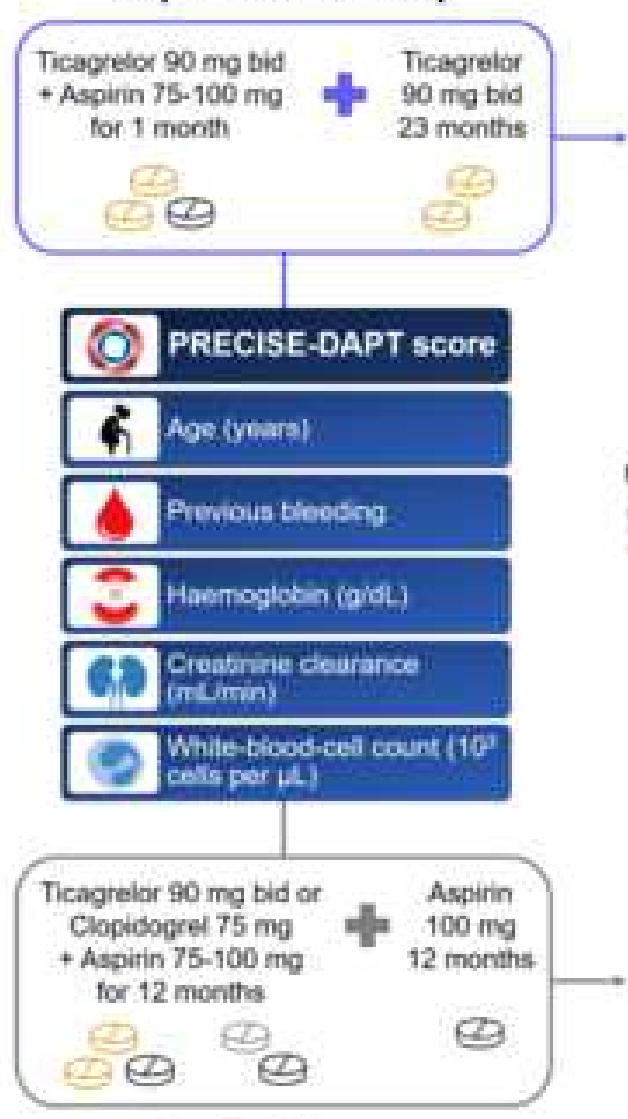

Control Group
Exprienental treatment strateey

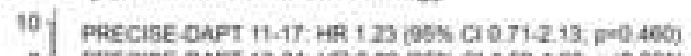

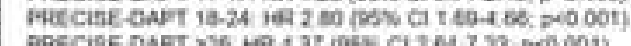

$\div 7$

ל⿺⿻一𠃋十

$\frac{n}{m}$

佥 PRECIBE DAPT 225 tQ 43 ? IOSS Ci 204723 peo 001 ?

\section{2.}

d $60 \quad 120 \quad 180240 \quad 300 \quad 360 \quad 420 \quad 460 \quad 640 \quad 600 \quad 660 \quad 730$ Days since indenx procedure

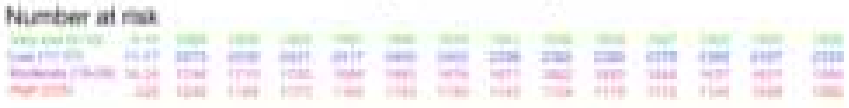

C

Relarence treatment strategy

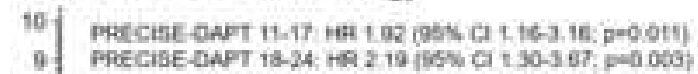

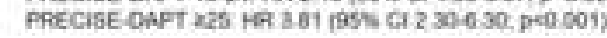

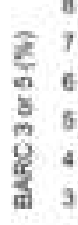
7
6
5
4
3
2
1
0 a.

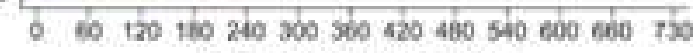
Days since insex procedure

Number at rist

\section{GLASSY}

B

Experimental treabment strategy

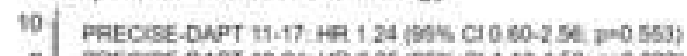

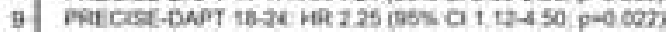

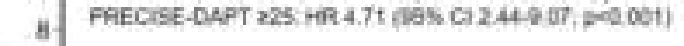

E. 7

क⿺

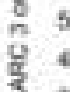

2.

i.

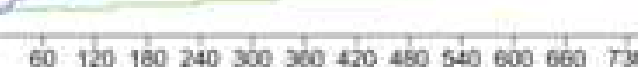

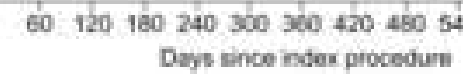

Namber at ina

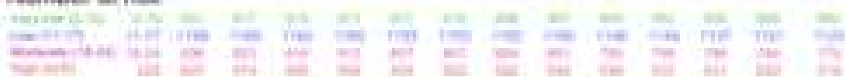

D

Reference treatment strategy

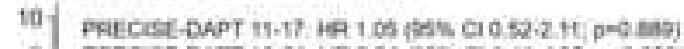

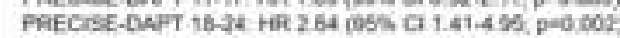

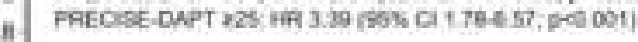

$\frac{\hat{c}}{2}$

0.

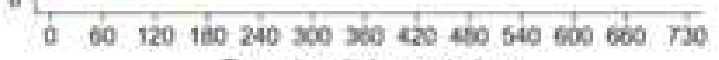
Days since index procedure

Namber all nat

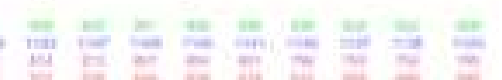


A

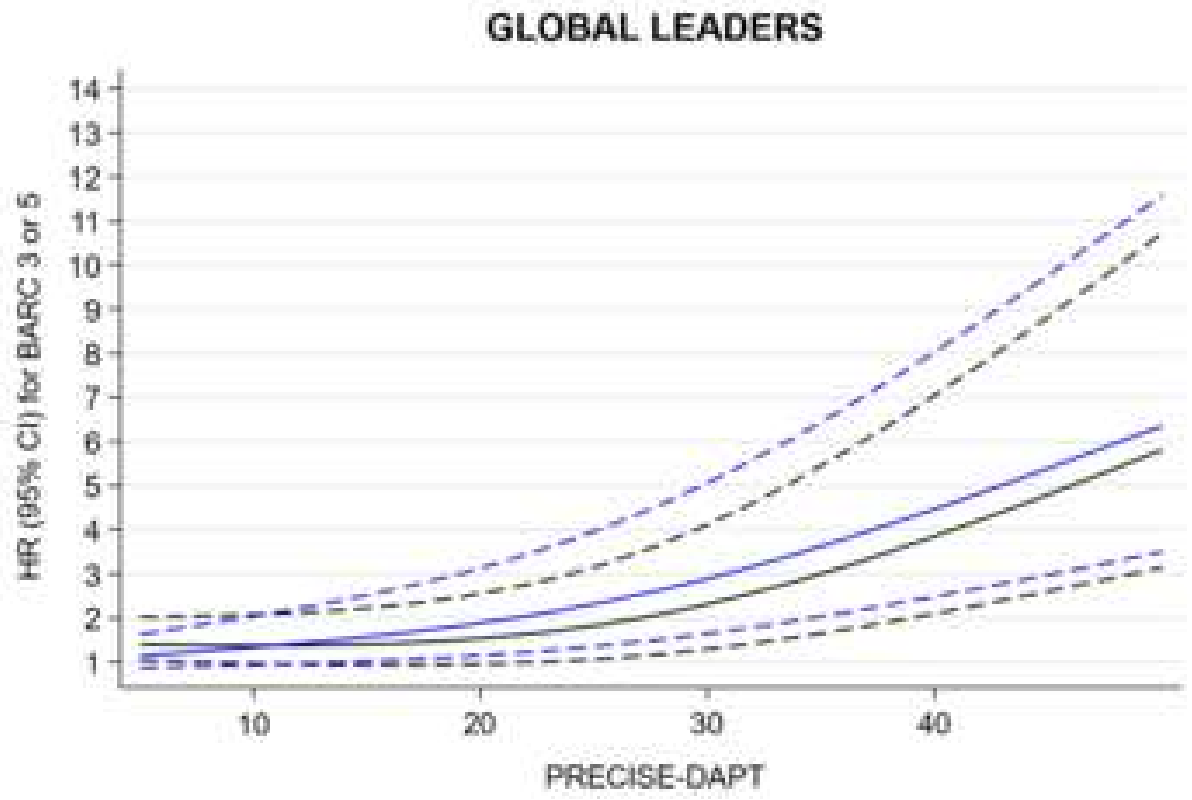

- Reterence group
$---95 \% \mathrm{Cl}$
$--95 \% \mathrm{cl}$
B

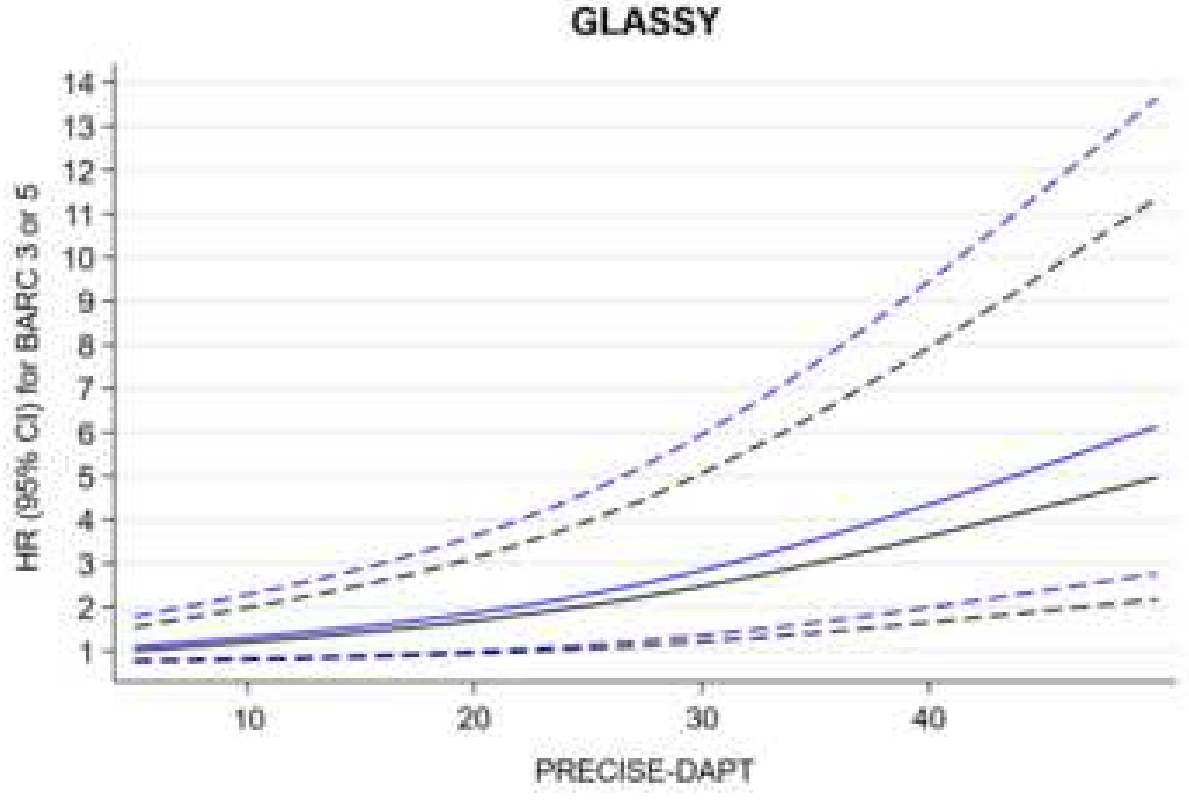

- Reterence group - Experimental group
$---95 \% \mathrm{Cl}$




\section{GLOBAL LEADERS}

A

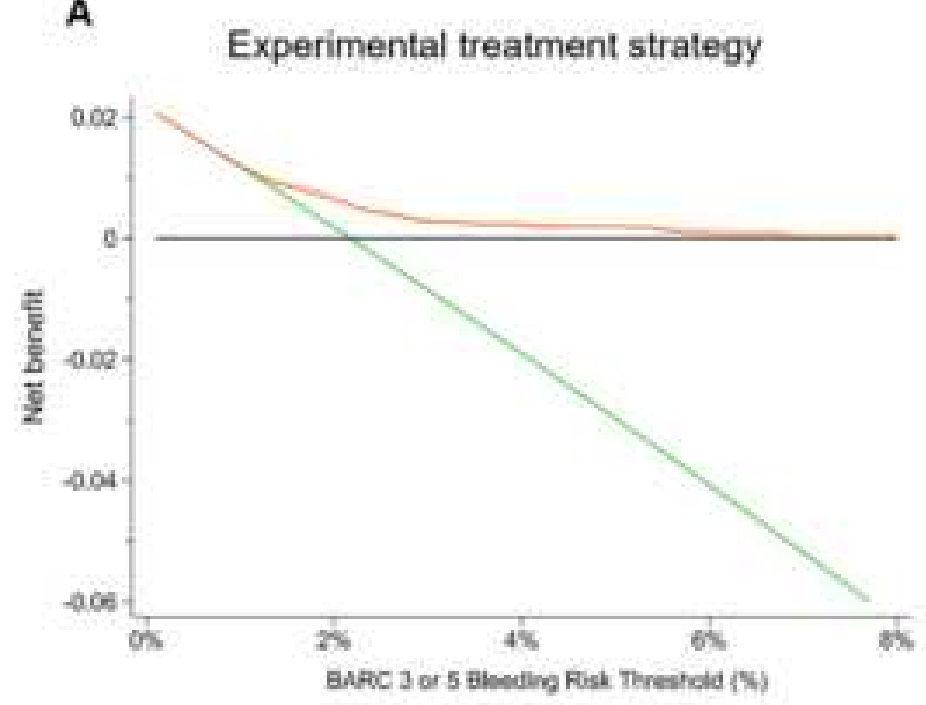

B

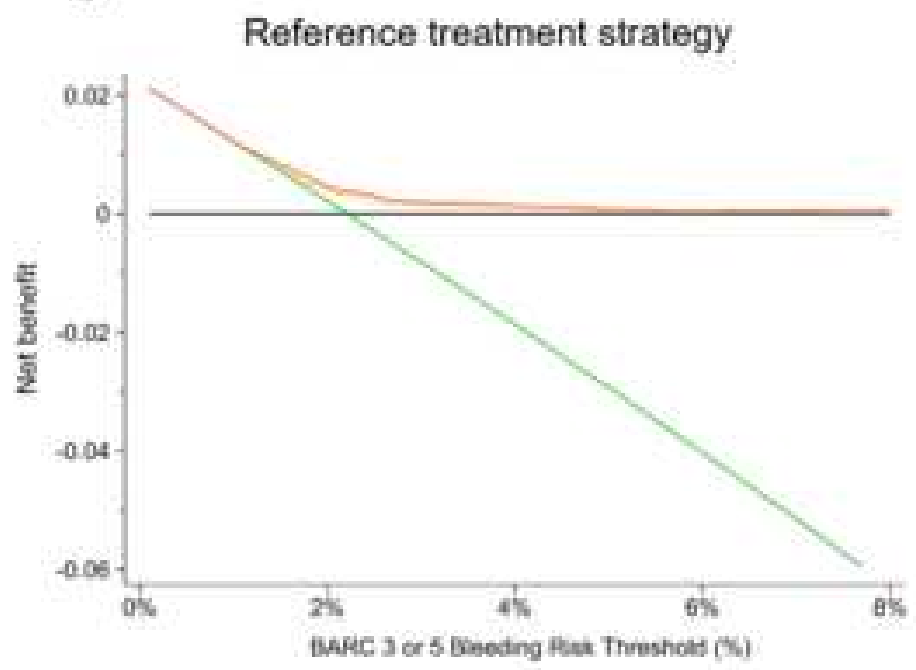

GLASSY

C

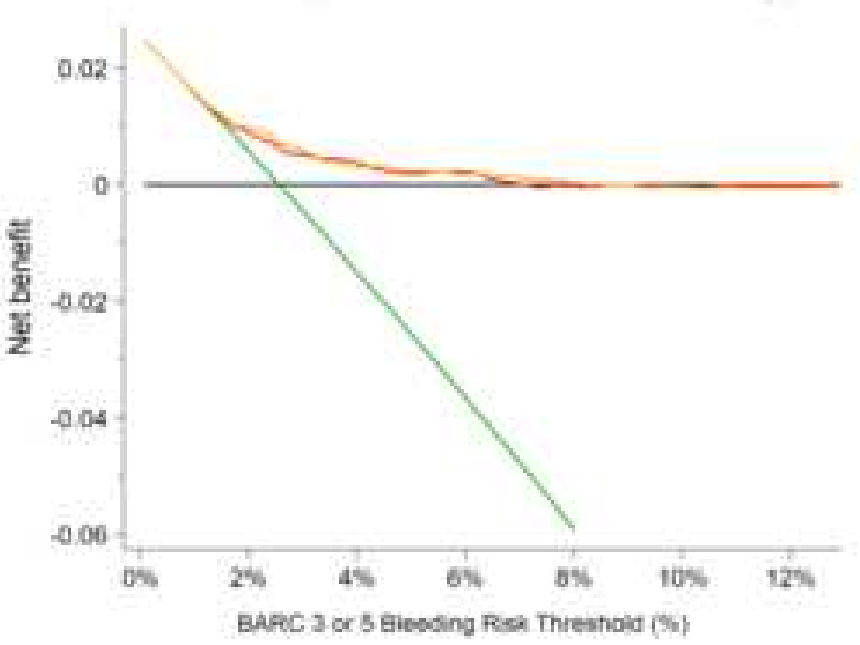

D

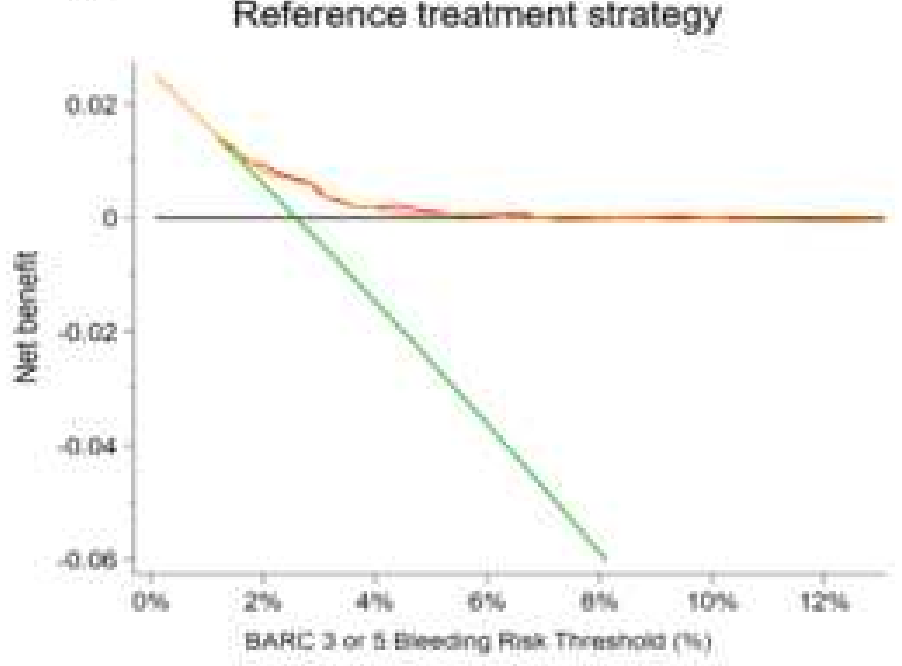

- Assuming all patients as low riak _- Assuming all patients as hagh-risk
- pHECSE-DAPT wore $\quad$ - 4hem Ppecise-DAPT scone 